\title{
FIELD EVALUATION OF THE EQUIPMENT AVAILABLE FOR RICE STRAW BALING
}

\author{
Bahaa El-Din Hemida*
}

\begin{abstract}
Reduction of environmental pollution is an important task for the Egyptian government. The burning of rice straw is one of the main sources of seasonal air pollution that known as black cloud. Rice straw may be used for several economical applications such as animal feed, animal house bedding, constructions etc. The loose nature of rice straw makes it difficult to handle rice straw from the field to the locations in which it is required. The availability of baling machines may attract the farmers to collect and sell rice straw bales instead of burning in the field. Several governmental organizations have been assigned to make the technology of rice straw collection and baling available for the farmers to control the phenomena of burning rice straw in the fields. Consequently, variable types of the locally fabricated as well as imported balers are available. The current research aimed to evaluate the performance of the most famous types of available balers in baling the mechanically harvested rice straw. The evaluated machines were; a) the locally fabricated tractor drawn and stationary rectangular balers, $b$ ) the imported tractor drown and stationary rectangular balers and, c) the imported cylindrical baler. The machines were evaluated for baling rate, straw losses (unpicked straw), bale density, loose bales, field capacity and efficiency.

The results show that pickup rate ranged from 42 to $62 \mathrm{~kg} / \mathrm{min}$ for all the tested balers. Stationery rectangular balers deliver up to 151 bale/h compared to 112 bale/h for the tractor pulled balers. Bale density for all the rectangular balers ranged from 131 to $146 \mathrm{~kg} / \mathrm{m}^{3}$. The performance of the locally made rectangular balers was very close to that of the imported balers either tractor drawn or stationary machines. Therefore, the locally made types of balers may compete in the local market and for export. The cylindrical baler forms stronger bales of larger size and higher density.
\end{abstract}

*Senior Researcher, AEnRI, ARC 


\section{INTRODUCTION}

ccording to El-Gindy (2009), the burning of crop residues is one
of national problems in Egypt especially after harvesting or
threshing operations to the different crops. The main objective in the present study is: Design, fabricate and evaluate the mechanical system of threshing and handling rice straw directly to the baler. A conveyor belt was designed to transport the rice straw from threshing machine to the baler. Selections of all bearings of the mechanical system were done according to the load carrying capacity. ending joints were checked against the stresses. According to Afifi et al (2002), in Egypt, there are about 1.5 million feddan cultivated area with rice each year. This resulted in nearly 4 million tons of rice straw. Most the farmers used to burn their straw yield at the end of the rice-harvesting season. This may have been considered as the reason for the phenomena known as black cloud that shrouds Cairo at the month of October every year. Field baling is essentially packing operation performed for hay and crop residues to facility handling, transporting, easy transport, processing and storing. Baling may be necessary for handling rice straw from the fields to the locations in which its economical utilization takes place. According to Nader (2010) some of the uses of rice straw are; dairy feeding, beef feeding, erosion control, livestock bedding, building construction and mushroom bedding. Results of environmental studies (California Agriculture Magazine, 1991) indicated that one tone of rice straw burning would produce about $56 \mathrm{~kg}$ of carbon monoxide (CO). Therefore, if only one million tones have been burnt each year, the total amount of carbon monoxide (CO) would have reached to 56,000 tones. This indeed, will cause increased the rate of air pollution that considers the primary reason of infection by cancer disease. Therefore, overcoming the rice straw problem has stimulated scientists and the Egyptian Government in finding alternative handling methods to protect the environment by preventing air pollution and health hazards. Baling the rice straw into rectangular or round bales is the important step in handling rice straw for other applications such as animal feeding, fuel, and fiber for paper manufacturing. Wang et al (2011) For resolving harvesting technology of fresh rice straw silage and plugging of the 
round steel-roll baler in China, experimental researches were carried out. For harvesting technology, baling silage and chopping silage were experimented. For the round baler, three kinds of feeding rolls equipped for enhancing feeding capability were experimented separately by reliability. Experimental results indicate: harvesting technology of baling fresh rice straw as silage is practicable; slicing-disc feeding rolls can be used to the baler to resolve plugging in straw-baling course. And through further experiments by reliability and density, optimal structure of the feeding roll is obtained: big and small slicing-discs arranged in interval and inclination, distance between slicing-discs being 30-40 $\mathrm{mm}$.

Abdel-Mottalb(1997) designed a new system to remove the field residuals by cutting, collecting, chopping and baling in one operation. It was designed by combining the vertical flail mower and the pick-up baler by modifying the designs necessary for hitching power transmission, $\mathrm{He}$ concluded that the unit area decreased with the increase of forward speed. Embaby (1985) under taken a field study to evaluate harvesting and baling operation of wheat in desert lands. The baling operation of wheat straw using pick-up baler was a function of baling rate (132.5) bales per hour with $0.118 \mathrm{~m} 3 / \mathrm{bale}$, (bale density $90 \mathrm{~kg} / \mathrm{m} 3$, machine efficiency 86\%) and the machine operator experience. El-Danasory and Imbabi (1999), studied the mechanical pick-up for packing of wheat straw after harvesting with combine. Results indicated that baler capacity was affected by weight of straw yield and forward speed. Baler losses decreased by decreasing forward speed and decreasing period after harvesting. They also stated that the of using balers to pickup baling straw was less than the half cost of manual method. Mosa (1994) constructed and tested a straw cutting and compressing device (baler) integrated with a combine. He concluded that rough straw present discharged from the chopper decreased by decreasing straw moisture content, increasing chopper r.p.m, and decreasing clearance, lower feed rates also resulted in lower rough straw percent. He also added that bales are more stable and less dense when they have a high percentage of rough straw. Straw length has significant influence on bale density. Shorter straw results in higher density bales. 


\section{MATERIALS AND METHODS}

The locally made balers as well as the commercially available imported balers were compared. The balers were technically field evaluated for baling rice straw as one of the most crop residue that urgently requires baling. The conditions of the test field may be presented in Table (1): Table (1) Conditions of the experimental field

\begin{tabular}{|c|c|}
\hline Item & Information \\
\hline Crop residual to be baled & Rice straw \\
\hline Straw density, $\mathrm{kg} / \mathrm{m}^{2}$ & 0.6 \\
\hline Residues quantity ton/fed & 2500 \\
\hline Type of Harvesting machine & General purpose combine \\
\hline Combine header width & $3 \mathrm{~m}$ \\
\hline Dimension of windrow & $1.0-1.2 \mathrm{~m}$ width $\times 40-60 \mathrm{~cm}$ height \\
\hline Straw weight, $\mathrm{kg} / \mathrm{m}$ of windrow & 1.8 \\
\hline
\end{tabular}

The study included variable machines that represent the all commercial baler types that are in use for crop residues baling operation. The machines included in the study may be classified as follow:

- Local made tractor trailed pick up baler

- Local made stationery baler

- Imported tractor trailer baler

- Imported stationery baler

- Imported round baler

The most important data of the balers may be presented in Table (2)

Table (2) Data of the tested balers

\begin{tabular}{|c|c|c|c|c|c|}
\hline Tem & $\begin{array}{c}\text { Locally } \\
\text { made t. } \\
\text { pulled }\end{array}$ & $\begin{array}{c}\text { Local made } \\
\text { stationery }\end{array}$ & $\begin{array}{c}\text { Imported t. } \\
\text { pulled }\end{array}$ & $\begin{array}{c}\text { Imported } \\
\text { stationery }\end{array}$ & $\begin{array}{c}\text { Imported } \\
\text { round }\end{array}$ \\
\hline Bale shape & rectangular & rectangular & rectangular & rectangular & round \\
\hline Piston dimension & $30 \times 40$ & $30 \times 40$ & $30 \times 40$ & $30 \times 40$ & $120 \times 125$ \\
\hline Baler dimension & $\begin{array}{c}6.0 \times 2.5 \times \\
1.6\end{array}$ & $\begin{array}{c}4.9 \times 2.5 \times \\
1.6\end{array}$ & $\begin{array}{c}4.97 \times 2.5 \times \\
1.76\end{array}$ & $\begin{array}{c}4.14 \times 2.45 \times \\
1.72\end{array}$ & $\begin{array}{c}4.43 \times 2.36 \times \\
2.21\end{array}$ \\
\hline Weight, kg & 1420 & 1510 & 1200 & 1535 & 1800 \\
\hline Pick-up width, cm & 146 & 150 & 130 & 140 & 167 \\
\hline Type of feeding & Pick-up & feeding & Pick-up & feeding & Pick-up \\
\hline Press mean & Mechanical & Mechanical & Mechanical & Mechanical & Hydraulic \\
\hline
\end{tabular}


The performance parameters considered in the current study were;

a- Baler pick up rate that computed as follow:

$$
\text { Baler pick up rate }=\frac{\left(W_{1}-W_{2}\right) \times S}{1000} \quad(\text { ton } / h)
$$

Where;

$W 1=$ weight of straw in $1 \mathrm{~m}$ of the windrow $(\mathrm{kg} / \mathrm{m})$

W2 $=$ weight of unpicked straw of the windrow $(\mathrm{kg} / \mathrm{m})$

b- Baler baling rate that is the number of bales delivered from the baler per one hour.

c- Straw losses (unpicked straw): weight of straw left from the windrow after the pass of baler.

d- Bale density;

$$
\text { Baledensity }=\frac{\text { Bale weight }(\mathrm{kg})}{\text { Bale volume }\left(\mathrm{m}^{3}\right)} \quad\left(\mathrm{kg} / \mathrm{m}^{3}\right)
$$

e- Percent of loose bales;

Percentof loose bales $=\frac{\text { Number of loose bales } / \text { operation day }}{\text { Totalbales produced in the operation day }} \times 100$ Field capacity and efficiency considering the time losses that related to operation and that related to breakdowns and repair in the field.

\section{RESULTS AND DISCUSSION}

Table (3) presents the performance of the tested balers. Weight of the rectangular bales of the tractor pulled and stationary balers ranged from 19 to $21 \mathrm{~kg}$. The round bale weight of the tractor mounted round baler was $120 \mathrm{~kg}$. Advancing speed of the tractor mounted rectangular baler ranged from 0.46 to $0.52 \mathrm{~m}$. Advancing speed of the baler that form round bale was about $0.55 \mathrm{~m} / \mathrm{s}$. Dimensions of the rectangular bale of the tractor mounted as well as stationery balers was $0.36 \times 0.4 \times 1 \mathrm{~m}$. The dimensions of the round bale of the round baler was $1.3 \mathrm{~m}$ diameter and $1.2 \mathrm{~m}$ length. 
Table (3) performance of tested balers

\begin{tabular}{|c|c|c|c|c|c|}
\hline \multirow{3}{*}{ Item } & \multicolumn{2}{|c|}{ Locally Fabricated } & \multicolumn{3}{|c|}{ Imported } \\
\hline & \multirow[b]{2}{*}{ Kader } & \multirow{2}{*}{$\begin{array}{l}\text { Helwan } \\
\text { stationery }\end{array}$} & \multicolumn{2}{|c|}{ Rectangle } & Round \\
\hline & & & Trailed & Stationary & Italy \\
\hline Moisture content of straw, $\%$ & $12 \%$ & $13 \%$ & $14 \%$ & $14 \%$ & $14 \%$ \\
\hline $\begin{array}{l}\text { Average baler advancing } \\
\text { speed, } \mathrm{m} / \mathrm{s}\end{array}$ & 0.46 & -- & 0.52 & -- & 0.55 \\
\hline Baler pick up rate, ton/h & 2.55 & 3.8 & 3.25 & 4.1 & 3.1 \\
\hline Baler pick up rate, $\mathrm{Kg} / \mathrm{min}$ & 42 & 61 & 48 & 62 & 52 \\
\hline $\begin{array}{l}\text { Unpicked material, } \mathrm{Kg} / \mathrm{m}^{2} \text { of } \\
\text { the windrow }\end{array}$ & 0.27 & -- & 0.25 & -- & 0.22 \\
\hline $\begin{array}{l}\text { Unpicked material, } \mathrm{Kg} / \mathrm{m}^{2} \text { of } \\
\text { the field }\end{array}$ & 0.09 & -- & 0.08 & -- & 0.07 \\
\hline Straw losses \% & $15 \%$ & -- & $14 \%$ & -- & $12 \%$ \\
\hline Ball average weight, $\mathrm{kg}$ & 19 & 21 & 20 & 21 & 120 \\
\hline Bale size (dimensions), $\mathrm{m}$ & & $0.4 \times$ & $36 \times 1$ & & $\begin{array}{l}\mathrm{D}=1.2 \\
\mathrm{~L}=1.2\end{array}$ \\
\hline Bale volume, $\mathrm{m}^{3}$ & 0.144 & 0.144 & 0.144 & 0.144 & 0.432 \\
\hline Bale density, $\mathrm{kg} / \mathrm{m}^{3}$ & 131 & 146 & 138 & 146 & 278 \\
\hline Capacity bale / h & 101 & 142 & 112 & 151 & 21 \\
\hline Field capacity Fedan $/ \mathrm{h}$ & 1.19 & 1.46 & 1.34 & 1.49 & 1.41 \\
\hline Efficiency, \% & $0.76 \%$ & $82 \%$ & $78 \%$ & $85 \%$ & $80 \%$ \\
\hline Loose bales, $\%$ & 2.6 & $1.8 \%$ & $2.2 \%$ & $1.5 \%$ & $1 \%$ \\
\hline
\end{tabular}

The basic functions of the balers are to pick up the residual from the windrow and to form baled. Figure (1) shows the balers pick up rate and the rate of forming bales. As shown in the Figure, stationery balers handle and compress within higher rate. The locally made stationery baler handles $61 \mathrm{~kg} / \mathrm{min}$ and the imported one handles $62 \mathrm{~kg} / \mathrm{min}$. Actually, the straw fed to the stationary balers by labors, so that the rate of feeding may depend on the labor. The tractor trailed balers handle less straw compared to the stationery balers. The locally made tractor trailed baler pick $42 \mathrm{~kg} / \mathrm{min}$ and the imported one pick $48 \mathrm{~kg} / \mathrm{min}$. The moving (tractor trailed) round bale baler pick $52 \mathrm{~kg} / \mathrm{min}$. The pick-up rate may depends on several factors from which the size and density of the windrow is the most important.

The rate of baling by the different balers may depend on the pick-up rate as well as the size and density of the bale. The size of the rectangular bale is so much smaller than that of the round one. Actually, the volume of the rectangular bale is about $0.144 \mathrm{~m}^{3}$ while that of the round one is 
$0.432 \mathrm{~m}^{3}$. Actually there is also large difference in bale density. Tractor trailed balers that form rectangular bale deliver $133 \mathrm{bale} / \mathrm{h}$ and $144 \mathrm{bale} / \mathrm{h}$ for the locally made baler and the imported one respectively. The stationery balers deliver 174 and 177 bale/h for the locally made and the imported baler respectively. The round baler delivers only $26 \mathrm{bal} / \mathrm{h}$ because the size and the weight of the round bale is much larger. The percent of straw losses or unpicked straw was determined for the moving balers. As shown in Fig (2), straw losses were 15\% for the locally made baler and $14 \%$ for the imported rectangular baler. The straw losses left behind the tractor driven round baler determined to be $12 \%$.

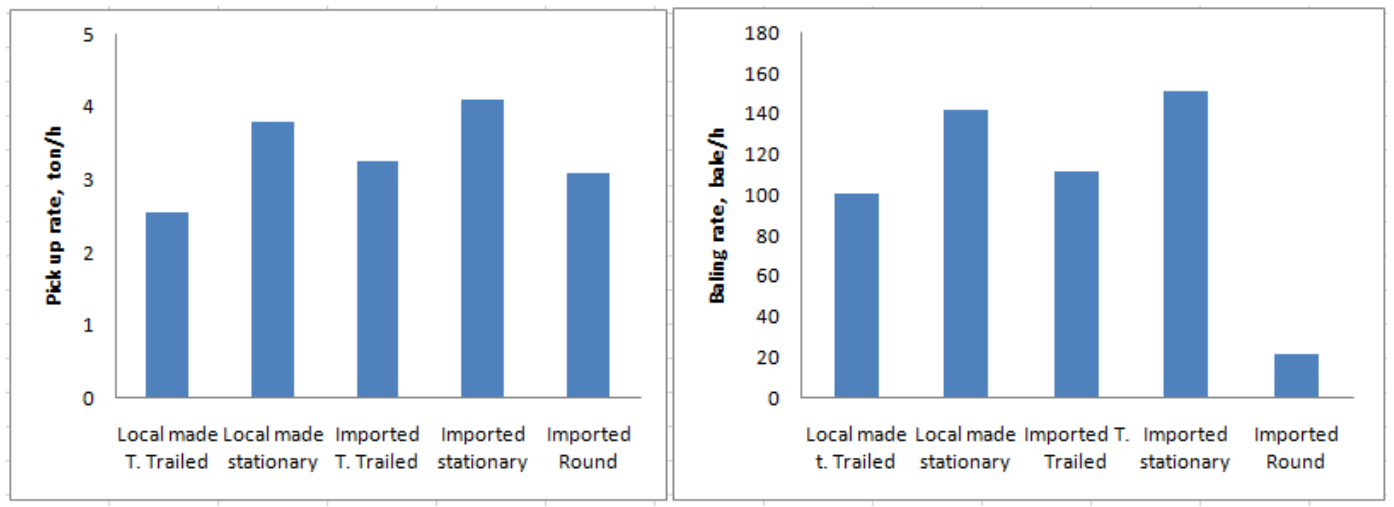

Fig (1) Pick-up rate and balling rate of the locally made VS imported balers

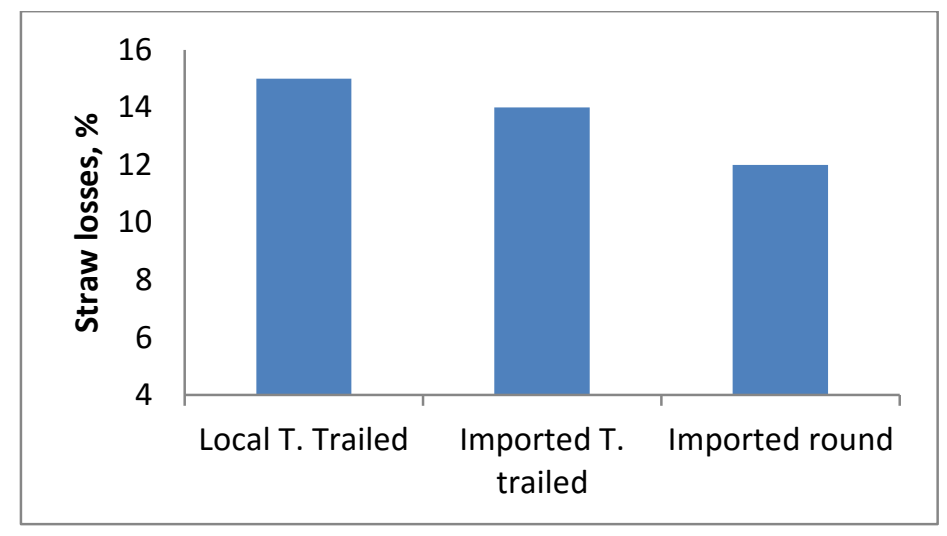

Fig (2) straw losses (unpicked straw) of the tractor pulled balers

Figure (3) show the bale density of the different tested balers. Bale density of the tractor driven rectangular balers is 131 and $138 \mathrm{~kg} / \mathrm{m}^{3}$ for the locally made and the imported balers respectively. The density of the 
rectangular bales of the stationary balers was $146 \mathrm{~kg} / \mathrm{m}^{3}$. The density of the round bale delivered by the moving round baler was as high as 278 $\mathrm{kg} / \mathrm{m}^{3}$.

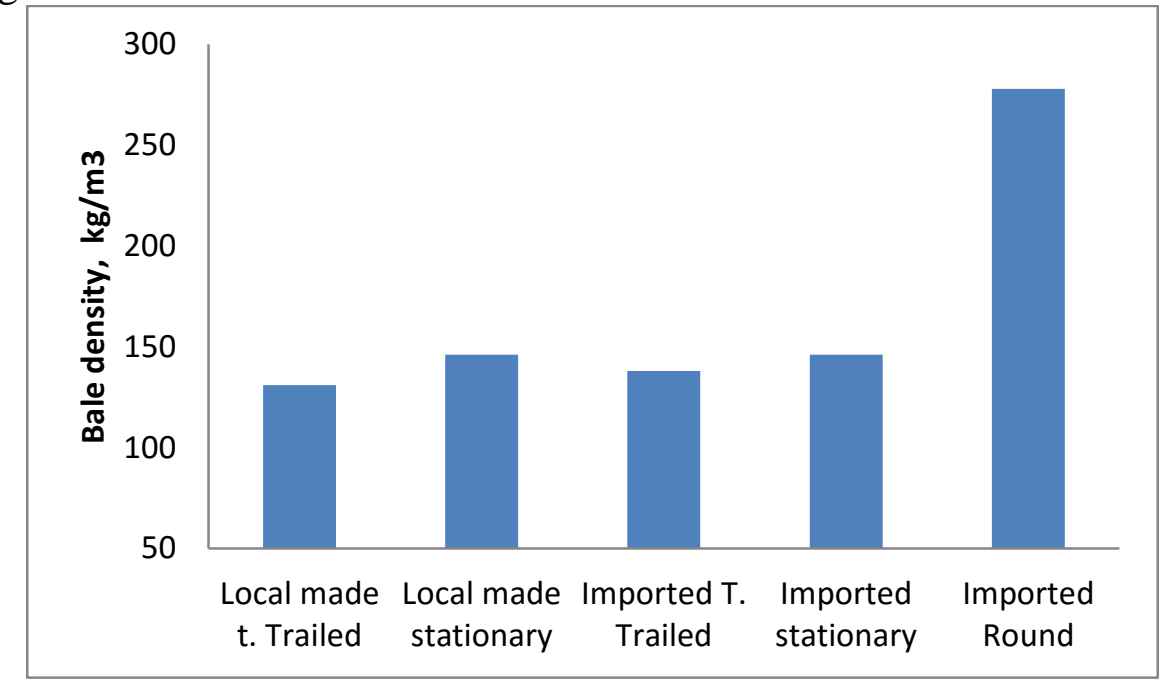

Fig (3) density of the bales delivered from different balers

The percent of loose bales as a result of continuous operation indicated in Fig (4). The Figure show that loosen bales ratio found behind the tractor pulled and driven balers determined to be over $2 \%$ either for the locally made or for the imported balers that deliver rectangular bale. The stationary balers deliver less percent of loose bales that estimated to be ranged from $1.5 \%$ to $2 \%$. Actually the proper maintenance of the baler may reduce the above mentioned ratio of loosen balers. The round baler performs better where the loosen bales was up to $1 \%$ only. Poor maintenance of any type of the balers expected to largely increase loosen bales.

Figure (5) show the field capacity and efficiency of the different tested bales. The field capacity of the stationery balers was computed considering the production of straw is 2.5 ton in average with no pick-up losses and the capacity was then computed in Fed/h. According to the above mentioned assumption, the capacity of the stationery balers was 1.46 and $1.49 \mathrm{Fed} / \mathrm{h}$ for the locally made and the imported balers respectively. Field efficiency for the stationery balers was computed 
considering the time losses due to breakdowns only. Consequently, the field efficiency of the stationery balers was $82 \%$ and $85 \%$ respectively. Field efficiency of the moving balers was $76 \%$ for the local made rectangular baler, $78 \%$ for the imported rectangular baler and $80 \%$ for the round baler.

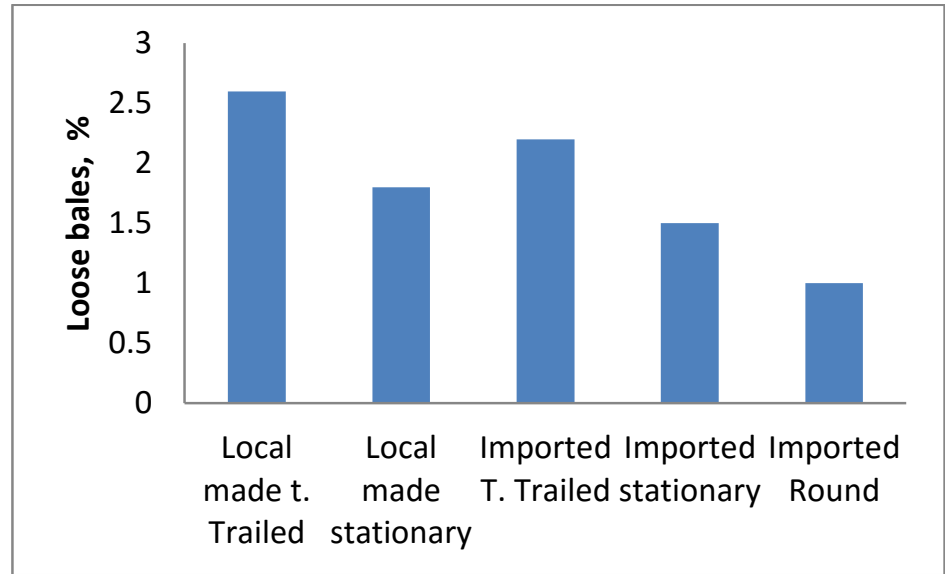

Fig (4) percent of loosen bales of the locally made VS imported balers
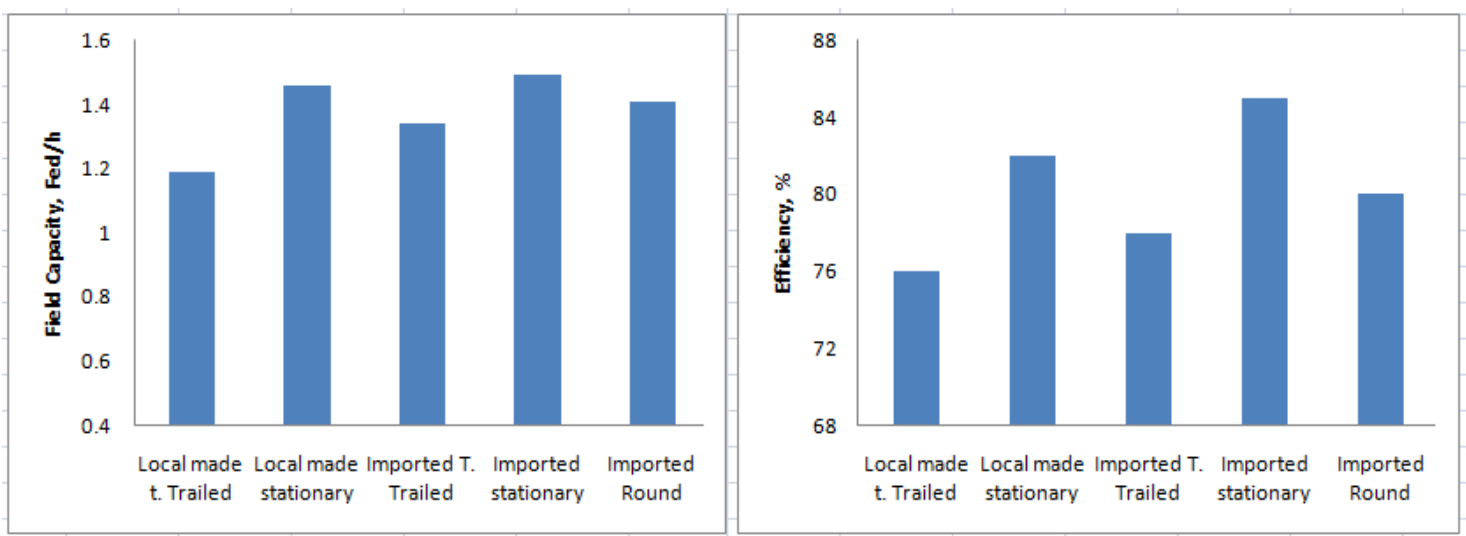

Fig (5) Field capacity and efficiency of locally made vs imported balers

\section{CONCLUSION}

The performance of the locally made and the imported balers was evaluated for pick-up rate, baling rate, bale density, loosen bales, field capacity and efficiency. The locally made rectangular baler pulled by the tractor performs very close to that imported one. The two balers deliver 
bales of similar size with the rate of 101 and 112 bales/h for the local and imported baler respectively. The field efficiency was $76 \%$ and $78 \%$ for the previously mentioned balers. The locally made stationery baler deliver 142 bale/h at efficiency of $82 \%$ and the imported one deliver 51 bales/h at the efficiency of $85 \%$. Bale density of all the rectangular balers either tractor pulled or stationery deliver bales of density range 131 to $146 \mathrm{~kg} / \mathrm{m}^{3}$. The round bale form large bales of $120 \mathrm{~kg} / \mathrm{bale}$ with field efficiency $80 \%$ and bale density $277 \mathrm{~kg} / \mathrm{m}^{3}$.

\section{REFERENCES}

Abd El-Mottaleb, A. F. 2002. Comparative study between pick up, stationary and round balers. Misr J. Ag. Eng., 19 (1) pp. 23-39

Afify, M. T.; A. H. Bahnasawy and S. A. Ali, 2002. Effect of rice straw picking up method on the performance of a rectangular baler. Written for presentation at the AIC 2002 Meeting CASE /SCGR program Saskatoon, Saskatchewan July 14-17. pp. 1-15

California Agriculture Magazine 1991. \#199 Volume 47 part 4 (July, August),

El-Danasory, M.M. and A.T. Imbabi. 1998. Study of mechanical and manual pickup and baling of wheat straw after harvesting with combine. Misr Journal of Agricultural Engineering 15(2):246-260.

El-Gindy, A. M. (1), Baiomy, M. A. (2), Abdelhameed, M. M. (2009) Design and fabrication of a simplified mechanical handling system of rice straw baling operation to reduce environment pollution. Misr J. Ag. Eng., 26(1): 667- 685

Embaby, A.T. 1985. A comparison of the different mechanization systems for the cereal crop production. M.Sc. Thesis (Agricultural Engineering), Cairo University, Cairo, Egypt.

Mosa, Magda M. 1998. Engineering factors affecting the development of grading machine for citrus. Ph. D. Thesis faculty of agriculture, Cairo University. 
Nader C A and Roninson P H (2010) Rice producers' guide to marketing rice straw. ANR Publications 8425: 1-10 ht Aanrcatalog.ucdavos.edu

Wang Defu, Dennis R.Buckmaster, Jiang Yiyuan, Hua Jinling. Experimental study on baling rice straw silage. Int JAgric \& Biol Eng, 2011; 4(1): 20 - 25.

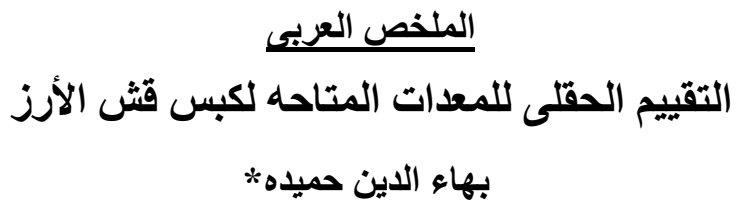

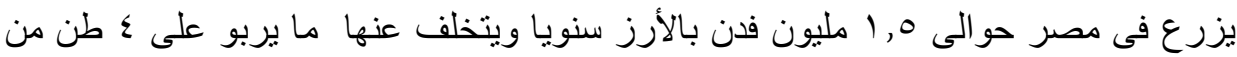

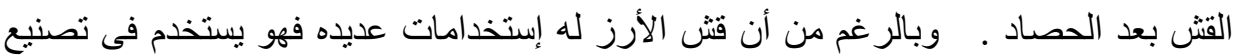

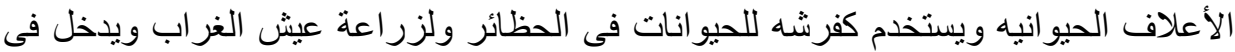

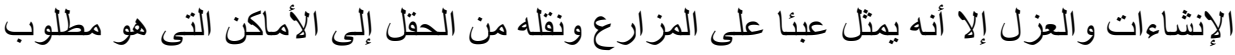

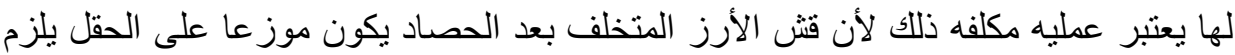

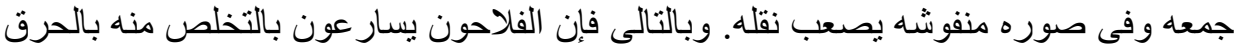

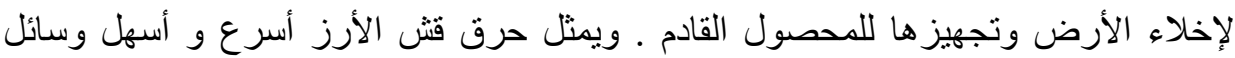

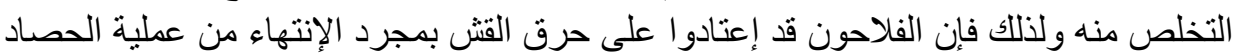

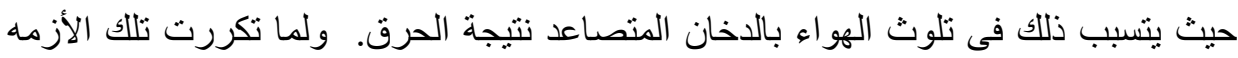

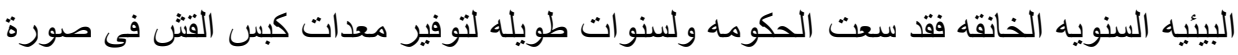

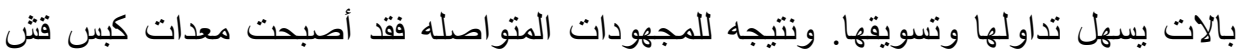

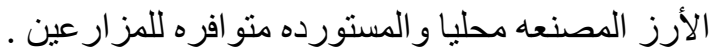

وقد أجرى تقييم حقلى لمعدات الكبس التى وجدت متاحه لدى المزارعين . وقد إثنمل البحث

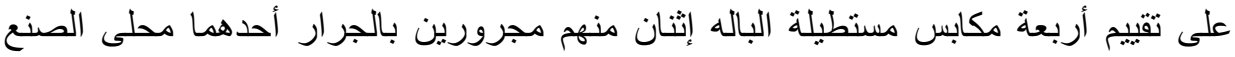

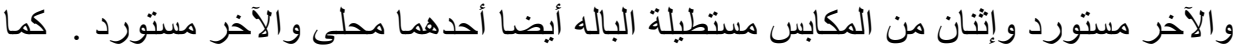

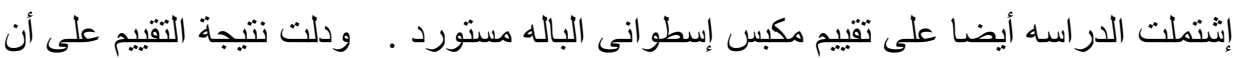

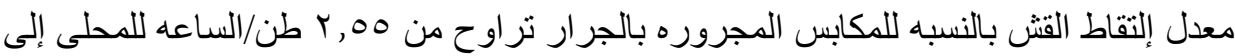

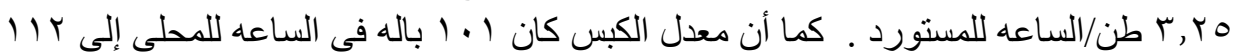

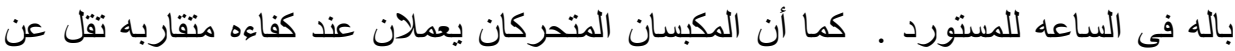

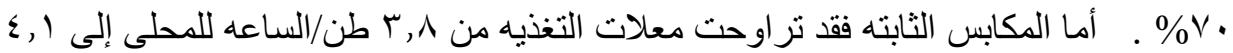

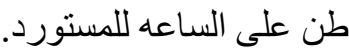

باحث أول بمعهد بحوث الهندسه الزراعيه 


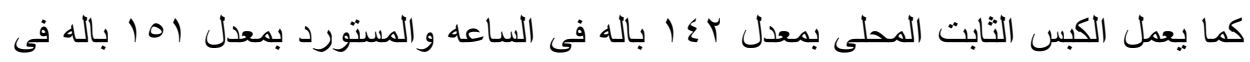

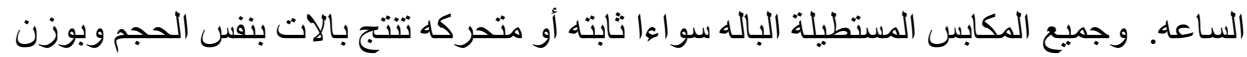

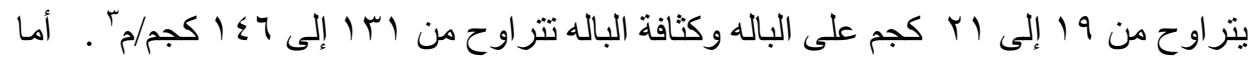

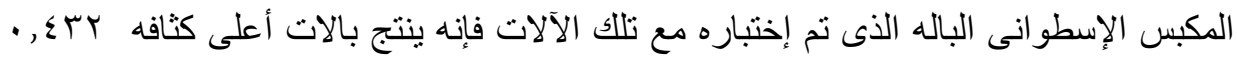

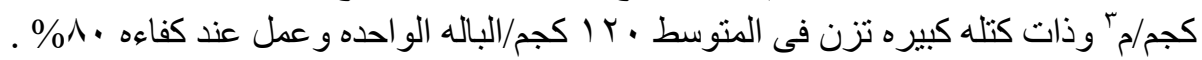

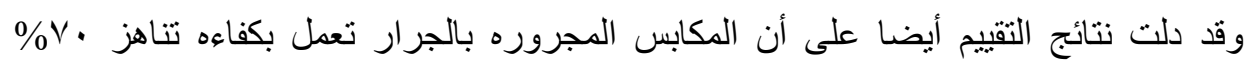

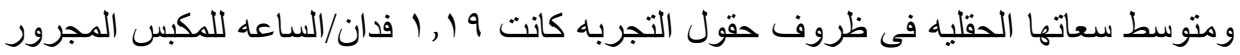

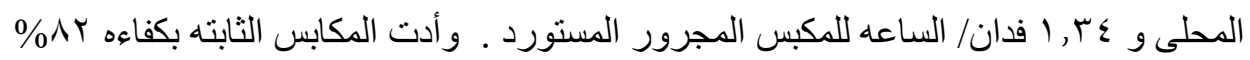

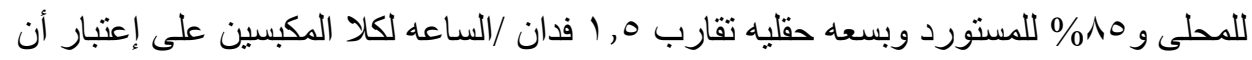

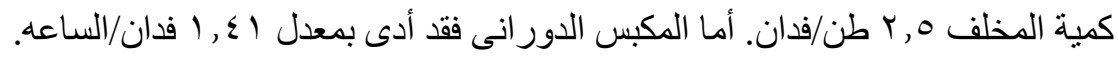

